\title{
FENOMENA MENURUNNYA INTEGRASI WARGA NEGARA TERKAIT TAWURAN REMAJA YANG TERJADI DI KABUPATEN BANDUNG BARAT
}

\author{
Penulis: \\ Kania Hasna Nafisah \\ 5111211068 \\ Fakhriza Amzali \\ 5111211069 \\ M. Restu Maolana \\ 5111211070 \\ Program Studi Manajemen Fakultas Ekonomi dan Bisnis \\ Universitas Jenderal Achmad Yani
}

\begin{abstract}
Abstrak
Integrasi merupakan hal yang penting untuk keharmonisan yang terjalin di lingkungan masayarakat Indonesia. Di zaman modern era globaliasi ini adanya penurunan satu kesatuan, banyak di kalangan generasi muda yang kurang kesadaran akan pentingnya saling membantu dan bersatu dalam kehidupan di lingkungan warga negara. Salah satu penyebab penurunan Integrasi ini adalah tawuran yang sering terjadi di masyarakat khususnya di kalangan remaja di daerah Kabupaten Bandung Barat yang menjadi alasan pecah belahnya masyarakat khususnya dikalangan anak muda. Oleh karena itu tulisan ini akan membahas aspek penyebab terjadinya tawuran remaja yang dilakukan secara studi pustaka. Dari hasil analisis aspek yang menjadi faktor tawuran yaitu psikologis sebagai remaja dan faktor lingkungan, hal tersebut sebab dari turunnya integrasi yang terjadi saat ini. Jika integrase dilakukan bersama-sama dengan serasi yang menghasilkan keharmonisan di kehidupan bermasyarakat maupun warga negaranya. Berdasakan atar belakang yang telah dipaparkan, penulis memilih menuliskan karya ilmiah dengan tema "Penurunnan Integrasi warga negara" yang bertempat di wilayah Kabupaten Bandung Barat.
\end{abstract}

Kata Kunci : warga negara, integrasi, Tawuran 


\begin{abstract}
Integration is important for the harmony that exists in Indonesian society. In this modern era of globalization, there is a decline in unity, many among the younger generation are less aware of the importance of helping each other and being united in life among citizens. One of the causes of this decline in integration is the brawl that often occurs in society, especially among teenagers in the West Bandung Regency area which is the reason for the division of society, especially among young people. Therefore, this paper will discuss aspects of the causes of juvenile brawls carried out in a literature study. From the results of the analysis of aspects that become a factor in the brawl, namely psychological as a teenager and environmental factors, this is the cause of the decline in integration that is currently happening. If the integration is carried out in a harmonious manner that results in harmony in the life of society and its citizens. Based on the background that has been described, the author chooses to write a scientific paper with the theme "Decrease in Citizen Integration" which is located in the West Bandung Regency area.
\end{abstract}

Keywords: citizen, integration, bra

\title{
PENDAHULUAN
}

Saat ini dunia telah memasuki era globalisasi dimana banyak budaya yang masuk ke suatu negara dan menimbulkan berbagai dampak positif maupun negatif. Dampak yang bisa dirasakan denganadanya globalisasi ini perkembangan pengetahuan, teknologi dan ekonomi yang semakin maju, terutama di bidang sosial banyak masyarakat yang lebih menyukai budaya luar negeri sehingga mulai hilangnya nilai-nilai budaya di Indonesia itu sendiri salah satunya adalah penurunan integritas yang terjadi di lingkungan masyarakat khusunya generasi muda penerus bangsa. 
Kabupaten Bandung Barat sebagai salah satu wilayah yang terletak di Jawa Barat tidak luput dari kekacauan seperti tawuran. Kejadian ini menjadi kekhawatiran semakin turunnya integrasi dan nasionalisme. integrasi yang ada di Indonesia ini memiliki makna utuh atau dengan bersatunya macammacam corak yang beragam jadi satu kesatuan utuh serta serasi. Dalam menjaga integrasi dan kesatuan yang ada di negara Indonesia ini, perlu adanya kebersamaan dalam menghadapi tantangan, karena Indonesia sendiri memiliki banyak suku, ras, agama yang diasatukan oleh Bhineka Tunggal Ika. Sebagai remaja yang akan meneruskan generasi bangsa patutlah untuk berperilaku yang sesuai untuk memertahankan integrasi dan kesatuan dengan berperilaku posistif dan menempa diri dalam kesempatan yang baik.

Kurangnya perhatian terhadap aspek lain membuat rasa integrasi mengalami dekadensi moral yang nyata. Saat ini, siswa menjadi lebih tidak terkendali, berorientasi pada pengelompokan, dan kekerasan dalam menjalankan aktivitasnya. Dalam menyelesaikan masalahnya, siswa cenderung melakukan kekerasan, tawuran, dan tawuran. Pelaku utama tawuran pelajar adalah remaja itu sendiri. Biasanya anak muda memiliki rasa solidaritas yang tinggi, terutama rasa solidaritas dalam kelompoknya. Solidaritas ini muncul karena adanya rasa kekeluargaan di antara kelompoknya. Mereka juga mengalami perasaan kecewa yang sama atau rasa tersinggung atas martabat mereka yang dilakukan oleh kelompok lain. Oleh karena itu, mereka menciptakan ikatan satu sama lain untuk berkumpul dalam satu kelompok.

Integrasi memiliki beberapa manfaat sebagai berikut:

1.kepedulian terhadap sesame dengan rasa satu kesatuan yang tinggi.

2. Hubungan bangsa yang erat membuat bangsa lebih kuat.

3. Menghagai sesame dengan adanya perbedaan.

4. Norma yang ada di masyarakat terjalankan dengan baik. 
Penulisan ini bertujuan untuk mengetahui faktor menurunnya integrasi khususnya pada remaja di lingkungan Kabupaten Bandung Barat.

\section{PEMBAHASAN}

Sebagai warga negara yan bertanggung jawab kepada bangsa, wajib memiliki kesadaran tentang berbangsa dan bernegara serta harus merasa berkewajiban menjaga ketentraman yang ada di masyarakat KBB dengan memelihara Iintegrasi dan kesatuan.

\section{A. Pengertian Integrasi}

Menurut KBBI Integrasi adalah pembauran sampai menjadi satu kesatuan yang bulat dan utuh. Adapun kata nasional berarti bangsa. Adanya pemahaan nilai Integrasi "bersatunya berbagai macam corak yang beraneka ragam menjadi satu kebulatan yang utuh dan serasi" bisa diartikan persatuan itu untuk mencapai kehidupan yang harmonis antar warga negaranya, dan menjadi faktor semangat perjuangan Indonesia.

\section{B. Pentingnya Integrasi di Masyarakat}

Integrasi di masyarakat sangatlah dibutuhkan karena jika hilangnya Integrasi ini akan menyebabkan konflik seperti kerugian secara mental maupun fisik materiil. Dengan tidak adanya Intregrasi tersebut membuat kemajuan bangsa tidak akan berprogres dengan baik khususnya di KBB. Integrasi ini bisa dimanfaatkan untuk mengembangkan potensi KBB agar membangun keberlangsungan hidup bangsan dan negara yang lebih terkelola.

Dengan kehidupan di era globalisasi membuat oknum masyarakat KBB bertindak sewenang-wenang yang menyebabkan konflik di masyarkat dengan contoh tawuran, dimana tawuran ini dapat terjadi karena kurangnya rasa integrasi di masyarakat KBB itu sendiri. 


\section{Pentingnya Integrasi Bagi Generasi Muda}

Menurut Winarni (2013) Pengintegrasian dapat dilakukan melalui pendidikan karakter dalam pembelajaran di sekolah maupun perkuliahan beserta mentoring dan juga evaluasi kegiatan. Disebutkan juga nilai moral bisa ditanamkan dengan beberapa cara sebagai berikut:

- Menciptakan lingkungan dengan menerapkan nilai moral yang berlaku di masyarakat, sehingga remaja terbiasa untuk menciptakan suasana moral yang baik

- Perlu adanya contoh peran dari guru atau orang tua untuk menunjukan sikap yang bermoral di kegiatan sehari-hari.

- Guru yang mengajar di sekolah bisa mendorong pelajar untuk mengembangkan nilai moral dengan menginspirasi untuk berlaku sesuai moral yang baik.

Dengan dilakukannya pendidikan karakter ini besar kemungkinan bagi generasi muda untuk menumbuhkan kembali rasa nasionalisme serta rasa persatuan yang erat.

\section{Pengertian Tawuran}

Menurut KBBI tawuran adalah perkelahian beramai-ramai; perkelahian massal. Tawuran bisa diartikan suatu kegiatan tindak kekerasan yang dilakukan sekelompok yang melakukan penyerangan kepada kelompok lain bisa dengan menyerang sampai saling membunuh. Secara psikis dan fisik remaja sedang dalam posisi masa transisi dengan emosi yang tidak stabil dan rasa ingin diakui yang tinggi, hal ini juga terjadi pada remaja yang tinggal di KBB tak sedikit remajanya yang memilih untuk berkumpul dan malah terjerumus di kegiatan negative. 


\section{E. Contoh Kasus}

Di kutip dari Liputan6.com, Kabupaten Bandung Barat - Pihak kepolisian sampai saat ini sudah menetapkan delapan tersangka dalam kasus bentrokan antar geng motor yang menyebabkan seorang bernama Muhammad Rahadiansyah (20) meninggal dunia akhir pekan lalu. Dua orang pelaku lainnya masih berstatus buron. Diketahui, insiden bentrok geng motor XTC dan Moonraker terjadi di Jalan Raya Purwakarta-Padalarang, Desa Nyalindung, Kabupaten

Bandung Barat, Minggu (28/2/2021). Akibat bentrokan itu seorang anggota Moonraker tewas dan beberapa orang terluka.

Kepala Satreskrim Polres Cimahi Ajun Komisaris Yohannes Redhoi Sigiro mengatakan, kedelapan anggota kelompok bermotor XTC itu sudah ditahan, termasuk pelaku yang menyebabkan korban meninggal dunia.

"Setelah diperiksa, hasilnya ada delapan yang ditetapkan sebagai tersangka dan sudah ditahan. Termasuk pelaku utama yang menusuk korban, sudah diamankan," kata Yohannes di Mapolres Cimahi, Selasa (2/3/2021).

Sebelumnya, pihak Satreskrim Polres Cimahi menetapkan lima tersangka.

Namun setelah dilakukan pemeriksaan secara intensif, kedelapan orang itulah yang terbukti ikut melakukan aksi penganiayaan hingga korban meninggal dunia.

Kejadian tersebut melibatkan beberapa remaja, ini menandakan adanya penurunan kualitas integrasi bangsa, dengan melakukan tawuran sama saja mengancam diri dari kematian. Nilai norma yang ada di masyarakat mulai memudar dengan digambarkan terjadinya tawuran antar kelompok. Kehidupan masyarakat yang seharusnya harmonis dirusak oleh kejadian seperti tawuran terutama dikalangan generasi muda yang nantinya akan meneruskan kehidupan bangsa Indonesia. 


\section{F. Faktor Penyebab Tawuran}

Faktor yang memicu terjadinya tawuran yaitu menurut Basri (2015):

\section{Psikologis Remaja}

Adanya perubahan psikologis pada remaja salah satunya menentang peraturan yang dianggap mengekang dirinya dengan melakukan kegiatan negatif, karena pada dasarnya mereka belum paham tentang diri sendiri. Sehingga mereka cenderung mencari apa yang mereka anggap menarik.

\section{Hilangnya Rasa Toleransi}

Kurangnya toleransi bisa menyebabkan perpecahan diantara masayarakat yang dapat menghambat keberlangsungannya kehidupan masyarakat. Remaja sebagai penerus bangsa akan rusak jika rasa toleransi hilang. Hal ini terjadi karena remaja yang terlibat kurang bisa menyesuaikan diri pada keanekaragaman budaya, pandangan, ekonomi dan lingkungan sekitarnya.

\section{3. keluarga}

Lingkungan keluarga yang kurang sehat seperti adanya kekerasan, bisa mempengaruhi mental remaja dan remaja bersangkutan akan mencari pelarian yang lain dan tak jarang masuk ke pergaulan yang salah. Pendidikan yang pertama didaptkan oleh anak yaitu berada di lingkungan keluarga, orang tua juga harus tahu bagaimana cara memberikan pengajaran pada anak, jangan terlalu diberikan kebebasan yang membuat kontrol yang tak terpantau. Pemberian didikan moral dan agama sangat diperlukan bagi kondisi pertumbuhan remaja.

\section{Krisis Identitas}

Krisis identitas merupakan hal dimana remaja tidak bisa menemukan identitas yang baik bagi dirinya sendiri, jika hal itu dibiarkan maka yang terjadi remaja akan mengambil jalan yang salah. Butuhnya pendampingan dari orang tua sangat membantu seorang remaja untuk bisa mengeksplorasi kegiatan yang positif. Sebagai seorang remaja kebanyakan ingin sekali mendapat pengakuan dari 
lingkungan sekitarnya, hal ini merupakan bagian dari psikologis remaja, rasa ingin diperhatikan ini yang menjadi jalan bagi remaja untuk melakukan hal yang tidak dipikirkan terlebih dahulu dan apa yang resiko yang ditimbulkan.

5. Kecerdasan emosi yang tak terkontrol

Kecerdasan emosi merupakan kemampuan untuk mengatur emosi, jika terjadi tidaknya emosi yang terkontrol menyebabkan emosi yang meledak dan kelakuan yang diluar kendali. Remaja ini akan condong tergesa-gesa menghadapi masalah dengan cara yang cepat membawa emosinya yang akan menimbulkan konflik batin, hal tersebut bisa menjadi asal mula terjadinya tawuran.

\section{G. Dampak Dari Tawuran}

Tawuran yang terjadi tentunya memiliki banyak dampak negatif diantaranya, menurut Purba (2015:8) dan Nawawi (201:7) :

- Merusak persatuan dan kesatuan.

- Dampak psikologi dengan timbulnya stress, frustasi, dan bahkan traumatis.

- Merusak fasilitas umum.

- Hancurnya kesatuan kelompok.

- Nilai dan norma social masyarakat menjadi hancur .

- Dengan adanya tawuran remaja yang bersangkutan bisa mengalami cacat, cidera bahkasn sampai kematian.

- Kurangnya rasa menghargai toleransi, norma dan perdamaian antar sesame manusia.

- Menimbulkan akibat jangka panjang di kehidupan bermasyarakat. 


\section{PENUTUP}

Integrasi yaitu pembauran yang berarti persatuan di kehidupan masyarakat yang harmonis yang harus diterapkan di keseharian dalam kegiatan di masyarakat, agar negara ini memiliki solidaritas yang tinggi untuk maju membangun bangsa yang lebih baik.

Dimasa kini adanya penurunan nilai integritas di masyarakat salah satunya tawuran. Tawuran merupakan tindakan kekerasan yang dilakukan suatu kelompok kepada kelompok lain yang bertujuan untuk menghancurkan, kejadia tersebut juga dialami oleh masyarakat yang dilakukan oleh remaja di sekitaran wilayah Kabupaten Bandung Barat, hal tersebut menjadi keprihatinan bagi warga sebab membuat risih di kehidupan social masyarakatnya. Faktor yang mempengaruh tindakan seperti tawuran pada remaja Kabupaten Bandung Barat yaitu kurang sadar akan adanya tolerasi, lingkungan pertemanan sampai keadaan keluarga yang kurang harmonis menjadikan beberapa remaja Kabupaten Bandung Barat mengambil jalan yang salah. Peran orang tua dalam mendidik anaknya sangat penting dengan meberikan arahan tentang integritas bagi masyarakat sejak dini, hal ini agar ketika anak tumbuh dewasa ia akan memegang rasa integritas yang tinggi.

\section{DAFTAR PUSTAKA}

Basri, A. Said Hasan. "Fenomena tawuran antar pelajar dan intervensinya." Hisbah: Jurnal Bimbingan Konseling dan Dakwah Islam 12.1 (2015): 1-25.

Kameliah, Nining. Tinjauan Kriminologi Konflik Mahasiswa dalam Kampus (Studi Kasus Tawuran Mahasiswa UIN Alauddin Makassar). Diss. Universitas Islam Negeri Alauddin Makassar, 2017.

Suneki, S. (2020, December). REVITALISASI CIVIC DISPOTITION DALAM MEMPERKUAT PERSATUAN DI ERA REVOLUSI INDUSTRI. In Seminar Nasional Keindonesiaan (FPIPSKR) (Vol. 2, No. 1, pp. 253260). 
Purba, Hendra, Holilulloh Holilulloh, and Yunisca Nurmalisa. "Persepsi Anggota Resimen Mahasiswa Universitas Lampung Terhadap Fenomena Tawuran Antar Pelajar." Jurnal Kultur Demokrasi 3.8 (2015).

Agus, Andi Aco. "Integrasi Nasional Sebagai Salah Satu Parameter Persatuan dan Kesatuan Bangsa Negara Republik Indonesia." Jurnal Sosialisasi: Jurnal Hasil Pemikiran, Penelitian dan Pengembangan Keilmuan Sosiologi Pendidikan (2016): 19-26.

Widyanti, Ayu Susan. Pengaruh Terpaan Pemberitaan Tawuran Antarpelajar Di Televisi Terhadap Sikap Pelajar Sma Negeri Di Kota Yogyakarta (Studi Deskriptif Kuantitatif Pemberitaan Kasus Tawuran Antarpelajar SMA Negeri 70 dengan SMA Negeri 6 Jakarta Periode 24 September 2012-30 September 2012 Terhadap Sikap Pelajar SMA Negeri 3 Yogyakarta). Diss. UAJY, 2013.

Winarni, Sri. "Integrasi pendidikan karakter dalam perkuliahan." Jurnal Pendidikan Karakter 1 (2013).

Kurniasih, Dewi. PROGRAM BIMBINGAN DAN KONSELING UNTUK MENINGKATKAN KECERDASAN EMOSI SISWA SMA: Studi PraEksperimen Terhadap Siswa Kelas X SMA RSBI Kota Bandung Tahun Ajaran 2010/2011. Diss. Universitas Pendidikan Indonesia, 2011.

Kurniasih, Dewi. "Pancasila Di Era Globalisasi." (2017).

\section{Internet}

Internet https://vi.scribd.com/mobile/document /1115 58407/pengertian tawuran, diakses pada hari senin, 15 November 2021, Pukul 23:01 https://id.scribd.com/doc/127674685/Pe ngertian-Persatuan-DanKesatuanBangsa,diakses pada hari senin, 15 November 2021, pukul 23:10 
https://www.liputan6.com/regional/read/ 4496649/tersangka-bentrok-gengmotordi-bandung-barat-bertambah-jadi-8orang, diakses pada hari senin, 15 November 2021, pukul 0:50

https://kbbi.kemdikbud.go.id/entri/integrasi diakses hari selasa 22 November 2021, pukul 22.21 